\title{
Rethinking Monetary Sovereignty: The Global Credit Money \\ System and the State
}

\author{
Steffen Murau, Boston University \& Bank for International Settlements, \\ smurau@bu.edu. \\ Jens van 't Klooster, University of Amsterdam \&, KU Leuven, \\ j.m.vantklooster@uva.nl.
}

Please cite as: Murau, Steffen, and Jens van 't Klooster. 2022.

“Rethinking Monetary Sovereignty: The Global Credit Money System and the State." Perspectives on Politics: 1-18.

DOI: $10.1017 / S 153759272200127 \mathrm{X}$

Available open access under:

https://www.cambridge.org/core/journals/perspectives-on-

politics/article/rethinking-monetary-sovereignty-the-global-creditmoney-system-and-thestate/33EE76D8B70FB954A03BF1124B79AA5C 


\begin{abstract}
This article proposes a new conception of monetary sovereignty that acknowledges the reality of today's global credit money system. The concept is today predominantly used to denote states that issue and regulate their own currency. This article rejects that Westphalian understanding of monetary sovereignty. Instead, we propose a conception of effective monetary sovereignty that focuses on what states are actually able to do in the era of financial globalization. The conception fits the hybridity of the modern credit money system by acknowledging the crucial role not only of central bank money but also of money issued by regulated banks and unregulated shadow banks. These institutions often operate 'offshore', outside of a state's legal jurisdiction, which makes monetary governance more difficult. Monetary sovereignty consists in the ability of states to effectively govern these different segments of the monetary system and thereby achieve their economic policy objectives.
\end{abstract}

Keywords: $\quad$ Sovereignty; money; financial ethics; global justice; global governance; international finance

\title{
1. Introduction 1
}

Even though monetary sovereignty remains an important reference point in both academic discourse and international politics, it has throughout the past decades repeatedly been

\footnotetext{
${ }^{1}$ Acknowledgments: We have presented earlier versions of this article at the 60th Annual Convention of the International Studies Association (ISA) in Toronto in March 2019 and at the Prospects of Money workshop at the Hamburger Institut für Sozialforschung in January 2020. We would like to thank all participants for their valuable feedback. Moreover, we are grateful to Benjamin Braun, Nik de Boer, Armin Haas, Elizaveta Kuznetsova, Perry Mehrling, Marco Meyer, John Morris, Fabian Pape, Eniola Soyemi and Anahí Wiedenbrüg who have read and commented on this article at various stages. Steffen Murau acknowledges funding from the German Academic Exchange Service (DAAD) and Deutsche Forschungsgemeinschaft (DFG). Jens van ' $t$ Klooster received support from
} 
declared dead (Strange 1996; Cohen 1998). There are good reasons for this. Creeping dollarization subjects states across the world to monetary and financial decisions made in the US (Cohen 2015; Fritz, de Paula, and Prates 2018). Local financial systems depend increasingly on globally active megabanks, asset managers, and hedge funds (Braun 2022; Naqvi 2019). Governments face global bond markets and the realpolitik of the IMF and the World Bank (Roos 2019). Regulators and supervisors across the globe struggle with cryptocurrencies, stable coins, and shadow banking instruments (Fama, Fumagalli, and Lucarelli 2019; Viñuela, Sapena, and Wandosell 2020). Meanwhile, even local banks in low income countries seek to comply with some version of the standards set at Basel's Bank for International Settlements (Jones 2020). Lacking the ability to control money within their borders, states have increasing difficulties to raise taxes and fund critical expenditures (Binder 2019; Palan, Murphy, and Chavagneux 2013; Zucman 2015). In what sense, if any, can states still be described as monetary sovereigns? (Pistor 2017; cf. Zimmermann 2013)

Today, the concept of monetary sovereignty is typically used in a Westphalian sense to denote the ability of states to issue and regulate their own currency. This understanding continues to be the default use of the term by central bankers and economists (De Grauwe 2012; King 2016) and in fields ranging from modern monetary theory (Kelton 2020) and from international political economy (Mabbett and Schelkle 2015) to international monetary law (Lastra 2015; Proctor 2012; Zimmermann 2013). As we argue in this article, the Westphalian conception of monetary sovereignty rests on an outdated understanding of the

the Dutch Research Council (NWO) under Grant 406.18.FT.014 and the Research Foundation - Flanders (FWO) under Grant 1227920 N. 
global monetary system and the position of states in it. This makes it unsuitable for the realities of financial globalization.

Building on foundational work in IPE (Cohen 1998, 2015; Strange 1996), recent scholarship on the monetary system has raised new challenges for the nation-state-centric focus of the Westphalian conception. For one, scholars increasingly highlight the crucial role of private money forms (Braun, Krampf, and Murau 2021; Gabor 2016; Gabor and Ban 2016; Gabor and Vestergaard 2016; Mehrling 2011, 2015, 2016; Murau 2017a; Pozsar 2014; Tooze 2018). In fact, public money forms, whose issuance is under the direct control of states, are only a small part of the global money supply. The larger share is made up of private credit money forms such as bank deposits and various forms of unregulated deposit substitutes, often termed 'shadow money'. This scholarship also casts further doubt on the Westphalian idea of states as equal constitutive building blocks of the international monetary system (Aldasoro and Ehlers 2018; Avdjiev, McCauley, and Shin 2015; He and McCauley 2012; Ito and McCauley 2018). Instead, the existing global financial system leaves money creation largely to private financial institutions which issue money 'offshore', using some of the world's most important units of account, e.g. the US dollar (USD), outside of the jurisdiction to which this unit of account is legally connected (e.g. the US).

Since the Westphalian conception rests on an inadequate understanding of money, it fails as a normative conception of sovereignty. The conception focuses on the legal competences of the state, which sovereign states are meant to exercise without interference from other states. But why should issuing and regulating a currency without interference matter so much? Although a national currency can indeed be an immense source of geopolitical power, the mere ability to issue a currency is by no means a guarantee for such 
power. Indeed, the existing literature on state sovereignty increasingly recognizes the conceptual limitations of conceptions of state sovereignty that focus on absence of interference (Dietsch 2011, 2015; R. H. Jackson 1992; Ronzoni 2009, 2012; Viehoff 2018). For this reason, political theorists have sought to rethink the concept to highlight its effective dimensions. Effective conceptions understand sovereignty as the ability of states to make meaningful choices and achieve their ends (Ronzoni 2012, 574). We turn to the monetary realm to develop an account of effective monetary sovereignty.

Rather than giving up on the concept of monetary sovereignty altogether, we reject the Westphalian conception and propose an alternative. The concept of monetary sovereignty is the general idea as it is widely used in economic and political discourse, while a conception is a particular way of defining the concept that distinguishes it from other conceptions (Rawls 1999). We propose an effective conception of monetary sovereignty that is distinct from the Westphalian conception. It focuses on what states are able to do within the constraints set by the global credit money system.

Monetary governance

\begin{tabular}{|l|l|}
\hline $\begin{array}{l}\text { Controlling } \\
\text { Public Money }\end{array}$ & $\begin{array}{l}\text { Regulating } \\
\text { Private-Public Money }\end{array}$ \\
Economic Policy Objectives
\end{tabular}

Figure 1-Monetary Sovereignty and the three dimensions of monetary governance 
In developing a new conception of monetary sovereignty, we understand the modern credit money system as composed of a public, a private-public and a private money segment. The agency of the state-what we describe as monetary governance-takes different forms in relation to these three segments. States can control public money through central bank design but can only exercise more arms-length influence over private money creation. The private-public segment of the credit money system consists in the regulated banking sector, which is subject to public guarantees and has access to monetary policy operations. The pure private segment consists in money creation that takes place outside the states' regulatory reach without public guarantees. It confronts states with a challenge of management, rather than regulation. In managing pure private money, states can seek to accommodate private money into the regulated banking system, issue an outright ban, or opt for a laissez-faire approach. Building on these observations, we understand monetary sovereignty in terms of monetary governance, which encompasses not only the issuance of public money forms, but also governance of regulated banks and unregulated money forms, onshore and offshore (see Figure 1).

In putting forward this new conception of monetary sovereignty, the article contributes not only to IPE scholarship but also to the emerging normative literature on the global monetary system (Bruin et al. 2018; Cordelli and Levy 2021; Herzog 2021; A. James 2012; Meyer 2021; Viehoff 2018; Wiedenbrüg 2021; Wollner 2018). As we show, understanding when states are able to achieve their economic policy objectives is crucial for determining what states in a vastly unequal and opaque monetary order owe to each other as a matter of justice. States may give up their national currencies while gaining effective 
monetary sovereignty. States can also have duties to limit their sovereignty understood in a Westphalian sense for other states to retain effective sovereignty (Ronzoni 2009, 2012). Accordingly, the conception of effective monetary sovereignty helps advance normative political theory on the financial system.

The remainder of the article is organised as follows. Section Two puts forward our conceptual framework which offers an account of the global credit money system and its relation to the state that will guide the analysis. Section Three builds on that account to argue against the Westphalian conception. Section Four develops the conception of effective monetary sovereignty. Section Five concludes. 


\section{A global credit money perspective on the state}

The past decades have seen scholars move away from the intuitive assumption that states are the crucial building blocks of the international monetary system. Although it was always recognized that states impact each other, these interrelations were often conceptualized in terms of self-contained monetary systems, whose operation is assumed to be under the control of the state. Long after the Bretton Woods System ended, the international dimension of the monetary system was theorized in terms of cross-border money flows, primarily by managing the conversion of their national moneys through exchange rate arrangements. This line of thought shaped the Mundell-Fleming model (Fleming 1962; Mundell 1963), which is the basis for influential analytical concepts such as the macroeconomic trilemma (or "impossible trinity") (Frieden 2015). According to the trilemma, states can only choose two of the following three policy objectives: fixed exchange rates, international capital mobility, and an autonomous monetary policy.

IPE scholars have done a lot to challenge the Mundell-Fleming perspective on the international monetary system. A first generation of IPE scholarship on international money have taken a step away from the Mundell-Fleming model by pointing to the fact that the idea of 'one nation, one currency' is an empirical chimera as national moneys are widely used in other countries (Cohen 1998; Helleiner 1994). In their view, today's global monetary system is shaped by currency competition (Cohen 1998, 2015; Strange 1996). States compete internationally to foster widespread usage of instruments denominated in their national unit of account. Those states that succeed acquire a powerful tool of economic policy. For those states that fail, the money within their territory becomes subject to foreign rules. Key examples are the 'dollarized' economies in the Global South, for instance in Latin America. 
This original critique of IPE stresses the cross-border usage of national currencies but still regards the creation of money as a national domain. Money creation is assumed to happen within the nation state, by the nation state, and still primarily for the nation state.

A new generation of IPE scholarship on international money-often operating in the context of 'critical macro-finance' (Dutta et al. 2020; Gabor 2020)—makes a second step away from the Mundell-Fleming world and emphasizes both the role of autonomous private money creation and of money creation that takes place offshore, outside of a state's territory (Binder 2019; Braun, Krampf, and Murau 2021; Gabor 2016; Gabor and Ban 2016; Gabor and Vestergaard 2016; Mehrling 2011, 2015, 2016; Murau 2017a; Murau and Pforr 2020; Tooze 2018). In this literature, the monetary system is understood as a global payments system in which all money is credit money, whether physically printed or not. Money creation takes place when a private or public institution expands its balance sheet and issues a new monetary instrument, e.g. a deposit, against a loan or bond. Offshore money creation denotes that private institutions use a national unit of account, say the USD, to create USDdenominated money outside of the United States. Through these analytical moves, the recent scholarship acknowledges what the Bank for International Settlements has called the end of the 'triple coincidence' when the monetary area, economic area, and decision-making area all coincided with a state's territory (Avdjiev, McCauley, and Shin 2015).

As we decouple the analysis of global money from nation-state centric categories, it is an open question what the remaining role of the state is vis-à-vis the global monetary system, and if and how it is possible to maintain ideas of states' monetary sovereignty under such perspective. To explore this question, we present a conceptual framework that systematically introduces the key concepts used in current IPE scholarship on international 
money, explains how they are interrelated, and highlights four crucial features of the state in the global monetary system.

The first feature is the state's role as a provider of units of account. A unit of account is a metric for denominating contractual obligations, which both public and private institutions use to denominate monetary instruments. For instance, the USD is the United States' unit of account, the British pound (GBP) that of the United Kingdom, and the euro (EUR) that of the European monetary union. In common parlance, the United States are said to issue 'the US dollar'. Such phrasing tends to overstate the case. First and foremost, the USD is nothing that would physically exist. As a unit of account, it is merely a benchmark that is required to denominate assets and liabilities in. Hence, a more exact wording would be to speak of USD-denominated instruments, some of which are issued by banks and other private financial institutions, and say that the US Federal Reserve issues "USD-denominated currency". Alfred Mitchell-Innes $(1914,151)$ states this crucial fact in saying that "the eye has never seen and the hand has never touched a dollar. All that we can touch or see is a promise to pay or satisfy a debt due for an amount called a dollar".

It is, however, by no means necessary that the units of account used in the global payment system are provided by states. Rather, this is an empirical fact of our age that emerged from a specific historical trajectory (Helleiner 2003). Private units of accounts are competing with the state prerogative, even though they have not reached a systemic role. Among those are cryptocurrencies such as bitcoin or tether which fluctuate against statebased units of account (Hayes 2021). The planned idea for a Facebook currency called libra would have been a similar case, based on the introduction of its own non-state unit of account (Libra Association Members 2018). Central bankers justify current initiatives for the 
introduction of central bank digital currencies (CBDCs) as defending the traditional monetary prerogative of the state (Brooks 2021).

The second role of states in our framework is that they take over various functions in relation to the issuance of money. Rather than simply creating money themselves as assumed in the Mundell-Fleming world, states provide a 'monetary jurisdiction' (Awrey 2017) as a legal space within which different institutions create different types of money, denominated in the state's unit of account. We distinguish three segments of the money supply, in relation to each of which the state's role takes different shapes.

First, public money is money issued directly by an institution that represents the state. The main instruments that correspond to the category of public money are central bank notes (or currency) and central bank deposits (or reserves). Today, public money is typically issued by an independent central bank, which uses the issuance of new money to pursue macroeconomic objectives outlined in a legal mandate (Garriga 2016; Lastra 2015). The introduction of a CBDC would add an additional instrument to the public money supply.

Second, private-public money is created by private institutions but guaranteed via explicit or implicit backstops by public institutions such as the central bank, the treasury or off-balance-sheet fiscal agencies (Guter-Sandu and Murau 2021). Even though the direct control of money creation is in private hands, issuance of private-public money forms takes place in the context of a strict regulatory framework provided by the state. Issuers will often need a banking license, but also receive access to last resort credit from the central bank and to deposit insurance that protects the customers of the issuer against default. Together, the guarantees serve to make private-public moneys for most economic purposes identical to public money forms. Straightforward examples of private-public money are insured bank 
deposits but the category also includes instruments such as overnight repos and shares of government money market funds if they are subject to public guarantees (Pozsar 2014).

Third, private money forms are issued by private institutions but do not have any public guarantees. These money forms need not be used as a means of payment themselves but are often merely convertible into means of payment instantly at face value. Monetary history has witnessed multiple shadow money instruments come and go, for example country bank notes in the $18^{\text {th }}$ and $19^{\text {th }}$ century, trust deposits in the $19^{\text {th }}$ and $20^{\text {th }}$ century, as well as money market fund (MMF) shares, repurchase agreements (repos) and asset-backed commercial papers (ABCPs) in the $20^{\text {th }}$ and $21^{\text {st }}$ century (Kindleberger and Aliber 2005). Definitions of what counts as private money or shadow money vary (Gabor and Vestergaard 2016; Pozsar 2014; Ricks 2016), which is hardly surprising as the opacity of those instruments is often part of their issuers' business strategy. Currently, scholars widely discuss if cryptocurrencies, in particular stable coins, are money and belong to this category (Fama, Fumagalli, and Lucarelli 2019).

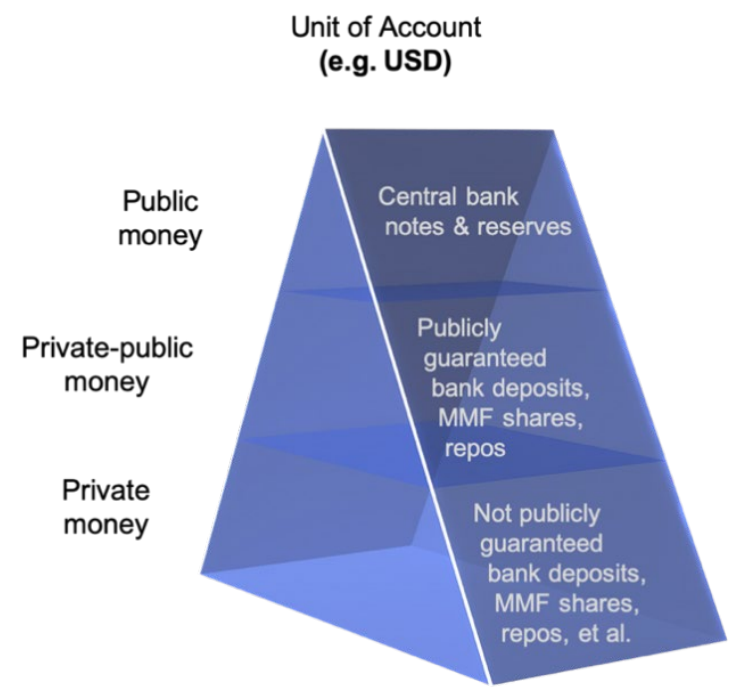

Figure 2-Public, private-public and private money segments 
Since the money supply in a monetary jurisdiction is a mix of different types of money, the state has a different role in relation to each. Figure 2 represents this public-private hybridity of the monetary system as a hierarchical three-layered pyramid structure.

From the conceptual perspective that we outline here, the defining feature that makes these instruments 'money'-in contrast to other instruments denominated in the national unit of account such as stocks or bonds-is that they maintain a one-to-one exchange rate with each other (i.e. they trade at par). You can easily transfer one USD note (public money) into a bank deposit (private-public money) by paying it into your bank account and then shifting it into an uninsured money market fund (private money), or vice versa. This often conceals important differences between these instruments (Gabor and Vestergaard 2016).

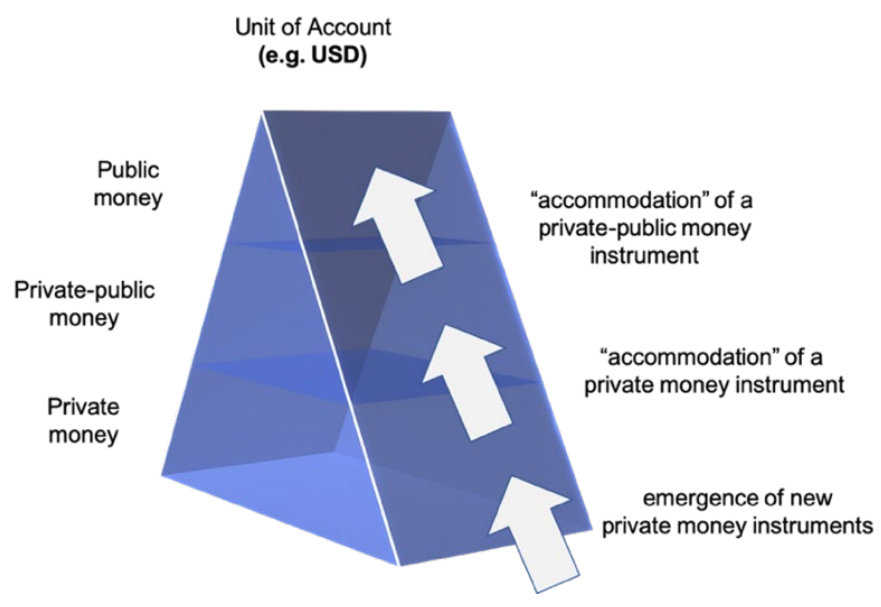

Figure 3-Mobility of money forms between segments

The public and private-public money forms we use today often originated as private money. They became systemically relevant over time, were subject to a bank run in a systemic financial crisis, and had to be turned into private-public money to prevent the 
monetary system from collapsing—a recurring process that Murau (2017b) calls 'private credit money accommodation' (see Figure 3). Today's central bank notes, or currency, originated as private credit money in the $17^{\text {th }}$ and $18^{\text {th }}$ century, were 'accommodated' in 1797 when the English Bank Restriction Act stopped gold convertibility and introduced a public guarantee for par clearance. The 1844 Bank Charter Act made them public money. Bank deposits are even older instruments that were turned into private credit money after the 1844 Act. In the US, bank deposits were accommodated in 1933 when Franklin D. Roosevelt announced a 100 percent guarantee to end the Great Depression. MMF shares and overnight repos developed as 'shadow money' in the 1970s and were accommodated in the 2007-9 Financial Crisis through the emergency interventions of the Federal Reserve and the US Treasury (Murau 2017b; Wullweber 2020). Accordingly, a money form is not firmly tied to one segment. Instead, private initiative can lead to the emergence of new money forms and state interventions can shift money forms around between the segments. Hence, states are not in the position to fully determine the structural setup of the money supply in their monetary jurisdiction but do have means to influence it.

The third feature of states in our framework is that they have some discretion over the degree of financial openness of their monetary jurisdiction. This is the underlying prerequisite for financial globalization, which not only pertains to capital account liberalization but crucially to the permission of offshore money creation (Braun, Krampf, and Murau 2021). The depiction of Figures 2 and 3 assume that the public, private-public, and private forms of money are created in the monetary jurisdiction of a state, using that state's unit of account as measure for denomination. This is the assumption that money creation occurs onshore. By contrast, offshore money creation takes place if institutions legally located 
in the monetary jurisdiction of one state issue monetary instruments denominated in another state's unit of account.

For example, a French bank in London can make a USD loan to a Chinese borrower and-in the course of this—create USD-denominated deposits outside of the United States. This form of offshore money creation began in the 1950s on the Euro-currency markets (Helleiner 1994), with the strong endorsement of the nexus between the City of London, the UK Treasury and the Bank of England (Burn 1999, 2006). With the end of the state-centric Bretton Woods System, the private Euro-currency markets attained an increasingly important role. From 1974, the Eurodollar market-the Euro-currency markets' core component-went global and became the backbone of the privatized international monetary system, centered around offshore US-Dollar creation (Braun, Krampf, and Murau 2021).

Not all credit money created offshore falls into the category of private money without public backstops. Through so-called swap lines, some central banks provide de facto backstops for credit money denominated in their unit of account in other monetary jurisdictions. The Federal Reserve and the ECB allow other central banks to provide USD and EUR-denominated credit money to their domestic banking sectors. In this way, both central banks have effectively put other central banks in the position to create public money in a foreign unit of account. This enables them to provide liquidity backstops to banks creating offshore bank deposits in their respective monetary jurisdictions, which then makes these deposits part of the private-public money segment. Other arrangements for backstopping banks are central banks' foreign exchange reserves, regional financing arrangements, and IMF credit lines. In these different ways, states are able to provide support to offshore money 
creation in units of account for which they do not issue public money (Denbee, Jung, and Paternò 2016; Mehrling 2015; Murau 2018).

Figure 4 integrates the onshore-offshore antagonism in our visualizations. The left part of the pyramid (dark blue) indicates the monetary jurisdiction, which is connected to the state's unit of account. The right part (light blue) summarizes all other monetary jurisdictions, within which the unit of account is used for offshore money creation. Taken together, the whole pyramid visualizes the monetary area of the given unit of account.

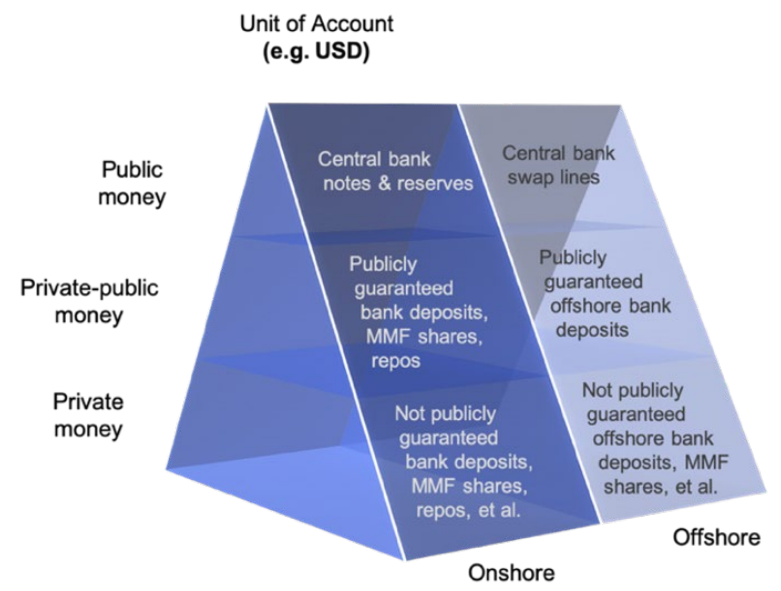

Figure 4-Three segments and the onshore-offshore antagonism

The fourth and final feature of states in our conceptual framework is their hierarchical positioning towards each other in the international system. States occupy different positions in the international hierarchy of money, which gives them greater policy space, and strive to improve their relative positions. This approach draws on an understanding of the international monetary system as the entirety of monetary areas based on states' units of account (Ito and McCauley 2018). Where the Mundell-Fleming model adopts a bottom-up view according to which all states are essentially equal building blocks, the recent IPE 
scholarship shows that states have a hierarchical relationship to each other that largely depends on the status of 'their' unit of account in the international hierarchy of money.

The notion that the international monetary system is hierarchical is not new to scholars of IPE. In fact, notions of hierarchy have famously been used by first-generation IPE scholars on international money such as Strange (1971) and Cohen (1998) who attribute a different status to different currencies, for instance top currency, patrician currency, elite currency, plebeian currency, permeated currency, quasi-currency and pseudo-currency. These scholars, however, remain to a certain extent in the framework of the MundellFleming model and assume that within the group of principally equal states, some issue a more important currency than others. In our framework, the international hierarchy is mainly a hierarchy of units of account, depending on the volume of their onshore and offshore usage. This determines the hierarchical position of the monetary area, which in turn shapes the position of the state in the international hierarchy, which again has substantial political implications for that state's policy space.

On all accounts, the unit of account at the apex of the international hierarchy is the USD. It has the most sizeable offshore component, which extends the scope of its monetary area far beyond the US monetary jurisdiction. Granting a paramount global role to the US state and its institutions, it pushes all other monetary jurisdictions into a peripheral position to the US (McCauley 2020). However, a point of contestation is how the international hierarchy takes shape below the apex. Traditional measures include the volume of currencies held in central banks' FX reserves (Eichengreen, Mehl, and Chiţu 2017) or the shares of turnover in FX transactions (Fritz, de Paula, and Prates 2018). 
To depict the international hierarchy, Figure 5 presents an idealized, incomplete sketch of the international hierarchy of monetary areas, using a variety of different units of account as examples. Following Murau, Pape and Pforr (2021), it orders jurisdictions with the international hierarchy in terms of access to the key currency in today's Offshore US-Dollar System. The highest layer is occupied by the USD. In the second layer, we find the euro area, which has the second largest offshore component after the USD, as well as Japan and the United Kingdom. Central banks in these monetary jurisdictions do not issue USD-denominated instruments themselves, but have access to the permanent unlimited USD swap lines of the Federal Reserve. On the level below, we find monetary jurisdictions such as Denmark, Australia, Brazil and South Korea, which have temporary limited USD swap lines. Most jurisdictions lack any access to swap lines and are situated in the lowest layer of this hierarchy.

The international hierarchy of money is not static, the relative importance of units of account and states is in permanent flux. The United States attained their dominant role in the interwar years when the British Empire lost its monetary hegemony (Harris 2021). The euro started as an attempt to establish a monetary counterweight to the USD, aiming to improve Europe's position in the international hierarchy (COM 1990). Its introduction has indeed had a major effect on the composition of the international hierarchy. Our figure also depicts Chinese efforts to further increase the offshore use of the renminbi ("RMB internationalization") as the political attempt of the government in Beijing to promote China's role in the world (Eichengreen and Kawai 2015) and eventually position itself as a competing monetary bloc outside of the US-dominated Offshore USD System (Murau, Rini, and Haas 2020). 


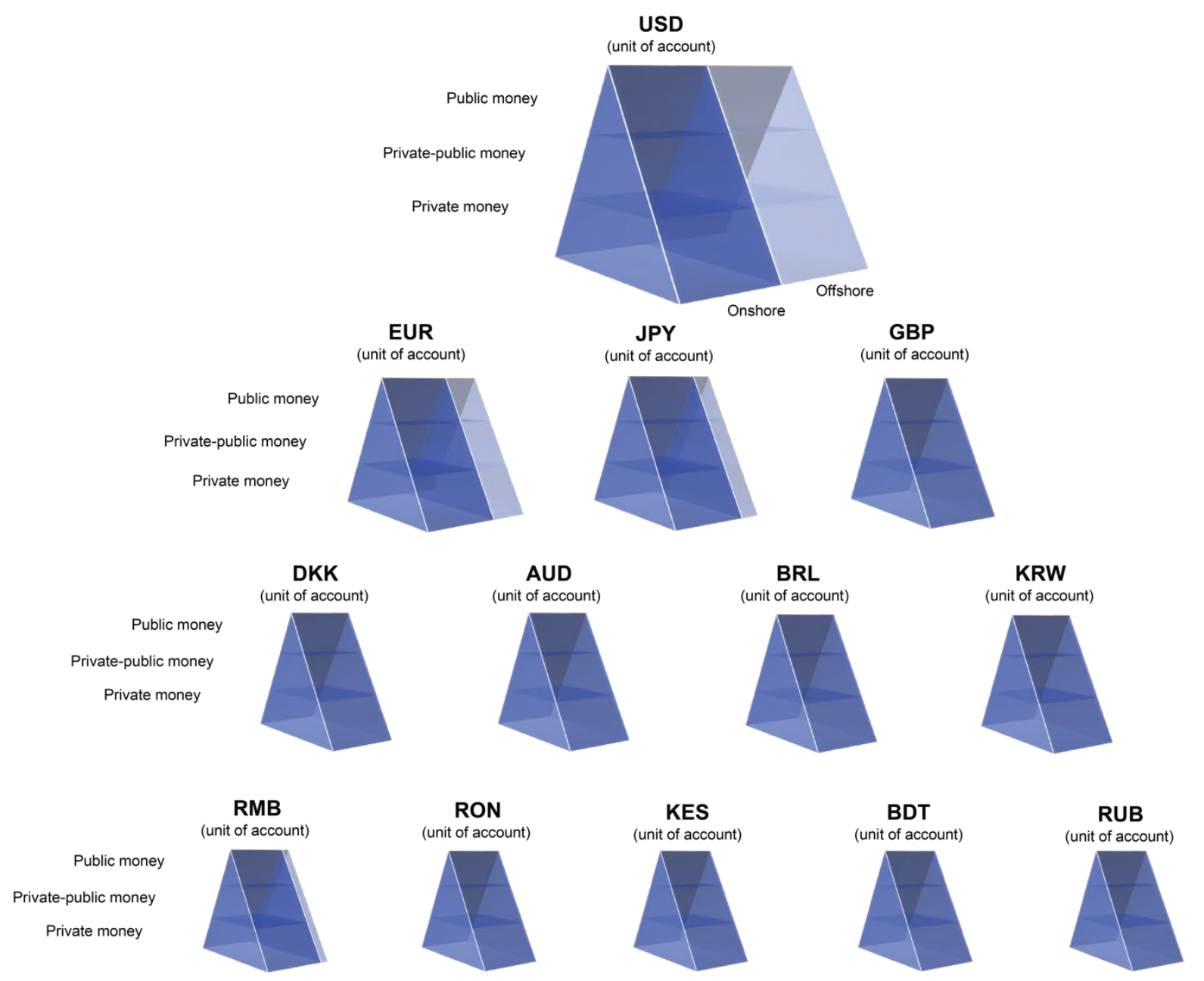

Abbreviations: AUD: Australian dollar; BDT: Bangladeshi taka; BRL: Brazilian real; DKK: Danish krona; EUR: Euro; GBP: British pound; JPY: Japanese yen; KES: Kenyan shilling; KRW: South Korean won; RMB: Chinese Renminbi; RON: Romanian leu; RUB: Russian ruble; USD: US dollar.

\section{Figure 5-The hierarchy of the Offshore US-Dollar System}

In sum, we conceptualize the international monetary system as a doubly hierarchical construct in which states provide the major units of account that are used to create different types of public, private-public, and private money-both onshore and offshore, and embedded in a multi-layered international hierarchical structure. This raises the question whether and how states can still have monetary sovereignty, which is the topic to which we now turn. 


\section{Beyond Westphalian monetary sovereignty}

The concept of monetary sovereignty is today predominantly used following a conception that we refer to as Westphalian. According to the Westphalian conception, monetary sovereignty consists in the ability of states to issue and regulate their own currency. Using the conceptual framework developed in section 2, we raise four objections to the Westphalian conception. This allows us to propose an alternative understanding of sovereignty in section 4 .

The concept of monetary sovereign is closely connected with the broader notion of state sovereignty. Although the concept has historically been used in a wide range of divergent senses (Loick 2019; Philpott 2011), it has often been taken to involve issuing a national currency (Proctor 2012). The $16^{\text {th }}$ century thinker Jean Bodin, who introduced the concept, explicitly names the ability to coin money as one of the defining aspects of sovereignty. The concept of sovereignty that today informs international law is a conception of state sovereignty that focuses on the right of states to exercise power over a territory without interference from other states. Originating in the $19^{\text {th }}$ century it is widely referred to as "Westphalian" after the $17^{\text {th }}$ century treaty that ended the Thirty Years' War.

In the monetary realm, international law defines monetary sovereignty as the right of states to make decisions with regard to their national currency. The legal principle of monetary sovereignty originates in a 1929 ruling of the Permanent Court of International Justice. In the so-called Serbian Loans Case, the court stated that "it is indeed a generally accepted principle that a state is entitled to regulate its own currency". Theorists of sovereignty have explored this principle by distinguishing an internal and an external dimension (Proctor 2012, para. 19.02-8; Zimmermann 2013). Internally, monetary sovereignty refers to the right of a state to issue a national currency, regulate its use within 
the territory and use monetary policy to achieve domestic policy objectives; externally, it refers to the ability to set the exchange rates. Used in this way, the Westphalian conception is informed by a vision of money closely connected to territory. It envisages a world where three features of states coincide: authority over the issuance of money, jurisdiction over a territory and the use of money within that territory.

Outside a narrow legal context, the concept of monetary sovereignty typically denotes the fact that a state issues a national currency which is widely used within its territory (De Grauwe 2012; King 2016; Lastra 2015; Mabbett and Schelkle 2015; Mitchell, Wray, and Watts 2019; Proctor 2012; Zimmermann 2013). Despite its widespread use, we argue that the Westphalian conception is not a particularly useful way to think about monetary sovereignty. We raise four objections.

Our first objection of the Westphalian conception is the narrow conception of the monetary system that informs it - it is focused on the public onshore segment of the monetary system. Today's international monetary system is hierarchical and dominated by private money forms. The most important and hierarchically highest currencies also have a sizable offshore component and a more prolific private-public and private money segment at the expense of the public money segment. Monetary jurisdictions that have high volumes of onshore public money forms exist at the very periphery of the global system. Bangladesh, for instance, has a proportionally large public money segment (Bangladesh Bank 2021a). At the same time, there is no or very limited offshore Taka creation. The focus on public money is least accurate exactly when it comes to the world's key currency. Within the US's monetary jurisdiction, the public money segment is relatively small compared to the private-public and the private segments. Within the private-public and private segments, moreover, the volume 
of USD issued offshore is larger than the volume of onshore USDs (Aldasoro and Ehlers 2018). No adequate conception of monetary sovereignty can omit these key segments of the money supply.

Second, the Westphalian conception obscures the very different positions of states within the global credit money system (Alami et al. 2021; Cohen 2015; Fritz, de Paula, and Prates 2018; Jones 2020; Pistor 2017). Although both the US and Bangladesh issue a national currency for use within the state's territory-i.e. are equally sovereign in the Westphalian sense-they take up very different positions in the international hierarchy of money. Since Bangladesh is highly reliant on the USD for trade and finance, it seeks to stabilize market fluctuations of its exchange rate (a so-called "managed float"). Its monetary policy is constrained by this objective, but monetary policy is only part of the story. As its domestic firms borrow in USD, its economy is structurally dependent on foreign lenders (Iqbal 2019). The key role of the USD in the global credit money system gives the US banking system a key edge over competitors and the Fed a powerful voice in shaping global banking regulation at the Basel Committee and other global regulatory fora. Bangladesh finds crucial parts of its banking system outside of its jurisdiction and is unrepresented in deliberation on global banking regulation. To stabilize its currency, Bangladesh holds a record of 46.4 billion USD in low-yielding currency reserves, while paying over 8 percent interest on its sovereign bonds (Bangladesh Bank 2019, 2021). The currency reserves are largely held in USDdenominated sovereign bonds. The functional role of US government debt as currency reserves and private sector collateral allows the US to fund historically unprecedented debt levels at much lower rates. Where the existing monetary system allows the US to achieve a 
range of economic policy objectives, the same is not true for Bangladesh. However, from a Westphalian perspective, both states are equally sovereign.

Third, as a consequence of its neglect of private and offshore money, the Westphalian conception overstates the importance of the ability of states to issue a national currency. This becomes clear if we look at one of the most important developments in the international monetary system in recent decades, namely the introduction of the European monetary union. According to the Westphalian conception, all countries that have joined the euro have given up their monetary sovereignty. To see that this is too simplistic, compare a euro area country such as the Netherlands with an opt-out country such as Denmark. In joining the euro, the Netherlands gave up its national currency, the guilder, and no longer sets its own monetary policy. Instead, monetary policy is made by the governing council of the European Central Bank (ECB), where Dutch interests are represented by its central bank governor. Membership in the European monetary union clearly affects how states pursue their domestic economic policy objectives, but that does not mean that they are more constrained than countries whose currency is pegged to the euro. The Danish krone is pegged to the euro at a fixed exchange rate, which precludes its use for pursuing an independent monetary policy (Wood 2018). The Dutch banking system benefits from membership in the monetary union and Dutch banks continue to be an important player in the global credit money system. There is of course a longstanding debate over whether joining a monetary union is actually the right choice for any given state (Gadha et al. 2021; Mody 2018; Pigeaud and Sylla 2021). However, despite lacking Westphalian monetary sovereignty, it is far from clear that the Netherlands is placed less favourably in the global monetary system than Denmark (Verdun 2021). 
This brings us to our final objection to the Westphalian conception, which is that it is too restrictive in its vision of what constitutes good economic policy. An adequate conception of monetary sovereignty should be compatible with a range of broader empirical and normative background assumptions. Similar to concepts such as "freedom" and "well-being", the question what constitutes "sovereignty" is itself a legitimate topic of political disagreement. Using it almost synonymously with specific policy prescriptions obfuscates the difference between monetary sovereignty and particular policies that contribute to it. Proponents of modern monetary theory, for example, have claimed that states only have monetary sovereignty if they meet all of three conditions: First, they issue a national currency in which they collect taxes, whose exchange rate is, second, floating and non-convertible, and, third, they have no foreign-currency denominated debt (Mitchell, Wray, and Watts 2019). To define it in this way reduces monetary sovereignty to a set of contested policy prescriptions, thereby seemingly resolving genuine political disagreement on a conceptual level (Bonizzi, Kaltenbrunner, and Michell 2019). A less prescriptive conception invites more sustained debate over what actually improves the position of states in relation to money.

Together, these four objections demonstrate that the Westphalian conception is simply inadequate. It is not a useful way to think about how the global monetary system helps or hinders states. As it does not track any weighty interests, it is of little help in exploring the rights and duties of states in the global monetary order. Consider the assertion that states should protect their own and respect other state's monetary sovereignty. Relying on the Westphalian conception, that claim may require too much from states. Sometimes states have to take measures to regulate the economy that are required as a matter of justice but limit their autonomy with regard to their national currencies. Respecting Westphalian 
sovereignty may also require too little. Westphalian monetary sovereignty may fail to provide states with the actual ability to govern money within their territory. Since it does not refer to something that should matter much to states, the Westphalian conception easily leads moral reflection astray and should be abandoned.

Should that observation lead us to declare the death of monetary sovereignty altogether, as Strange (1996) and Cohen (1998) have suggested? We think that its widespread use in academic discourse and international politics should lead us to rethink rather than abandon the concept. In fact, turning to the literature on political sovereignty, it is clear that the Westphalian conception is not the only way of defining monetary sovereignty. Political theorists have long challenged Westphalian conceptions of state sovereignty as a normative benchmark for international relations (Dietsch 2011, 2015; R. H. Jackson 1992; Ronzoni 2009, 2012). These authors, too, have raised the worry that a narrow focus on non-interference is both too demanding and not demanding enough. It is too demanding in that it sees treaties in which states give up selected legal competences as reducing sovereignty, even where these treaties improve the capacities and resources available to states to achieve their domestic policy objectives (Ronzoni 2012). It is not demanding enough since it requires little more from other states than the absence of interference (R. H. Jackson 1992, 40-47). States can retain the legal competences to issue and enforce regulation while lacking the capacities and resources to achieve their domestic policy objectives. A thoroughly unjust order of weak states can respect national borders.

The theory of political sovereignty has therefore undergone a substantial change, moving beyond the Westphalian conceptions of state sovereignty to a conception of effective sovereignty. Political theorists have argued for a renewed focus on the policy options that are 
available to states and the outcomes that they can achieve (Dietsch 2011, 2015; R. H. Jackson 1992; Ronzoni 2009, 2012). Invoking the classic distinction of Isaiah Berlin between negative and positive liberty (Berlin 1969; R. H. Jackson 1992), they reject the legal conception's focus on non-interference and instead highlight the importance of normatively valuable outcomes that states can achieve. Understood in a "positive" or "effective" sense, sovereignty is then taken to refer to "the substantive problem-solving capacity of states and to their ability to make meaningful and genuinely discretionary choices on a range of issues" (Ronzoni 2012, 574). A similar turn, however, has not taken place with regard to the concept of monetary sovereignty, which reflects the modest size of the existing normative literature on the state in relation to the global monetary system (Bruin et al. 2018; Dietsch 2021; Herzog 2019; A. James 2012; Reddy 2003; Viehoff 2018). We therefore propose to make this overdue turn in our understanding of monetary sovereignty and move from the Westphalian conception to a conception of effective monetary sovereignty. 


\section{Effective monetary sovereignty}

Rather than focusing on the issuance of national currencies and the absence of foreign interference, effective monetary sovereignty concerns what states are able to achieve within the confines of the global credit money system. We define effective monetary sovereignty as the state's ability to use its tools for monetary governance to achieve its economic policy objectives.

Since we propose a conception of monetary sovereignty and not an empirical benchmark or policy prescription, our account does not imply any particular vision of how states should govern their monetary systems. What objectives states pursue is their decision to make. In the postwar era of "embedded liberalism", states often subordinated their economic policy to full employment, while post-1980s monetary orthodoxy emphasized price stability and economic growth as overriding concerns (Blyth 2002; COM 1990; Monnet 2018). Today, policymakers are increasingly concerned about financial stability, climate change and biodiversity loss (Paterson 2021; Smoleńska and van 't Klooster 2022). Effective monetary sovereignty concerns the state's ability to set its economic policy objectives and govern money accordingly.

How the state governs money takes different shapes in relation to the three segments

of money within its monetary jurisdiction (see Figure 6). The Westphalian conception of monetary sovereignty is focused on public money forms, which are indeed directly issued by public institutions. In this sphere, monetary governance involves direct control over the issuance of money. The private-public segment consists in money issued by banks and other private institutions within a strict public legal framework. Bank deposits and other means of payment benefit from public guarantees but are subject to strict regulation. A distinct private 
segment escapes the strict regulatory regime for banks but is still subject to its own regulatory framework. Here, effective monetary sovereignty is limited to efforts to manage the money supply.

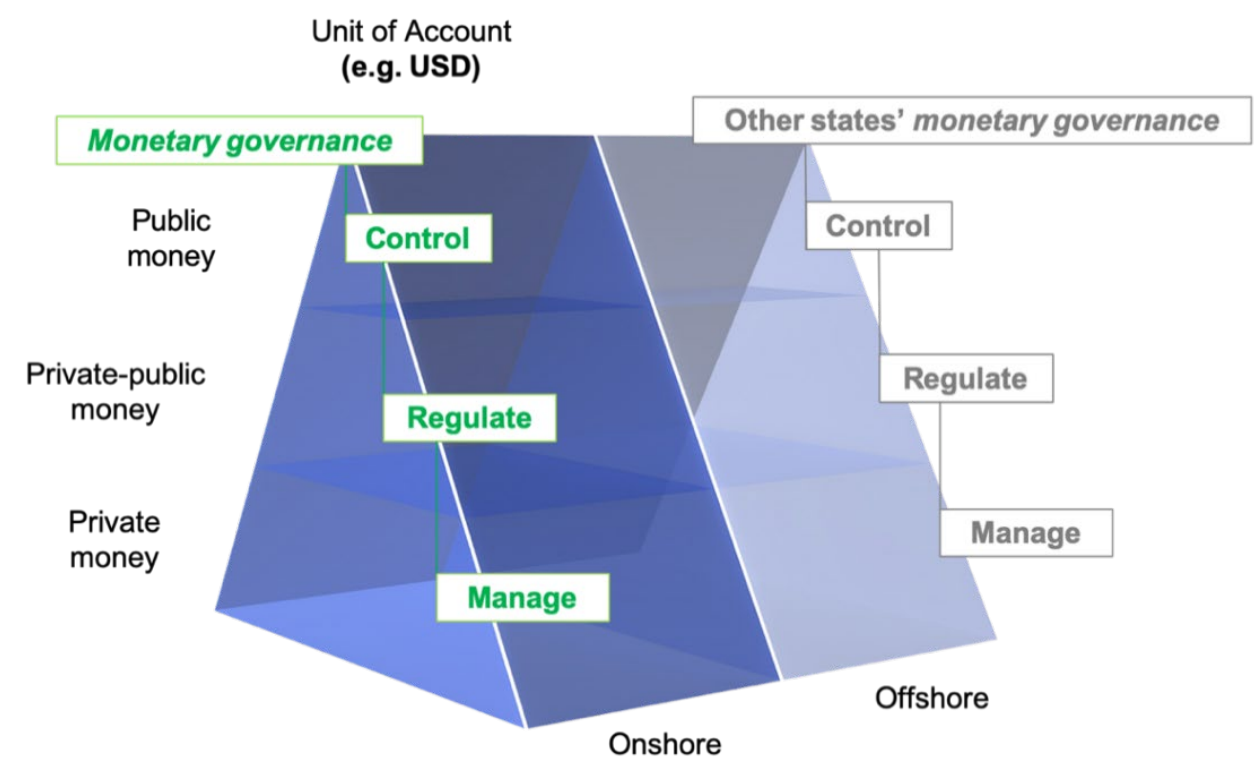

Figure 6-Monetary governance and the three segments of the money supply

Effective monetary sovereignty fits the existing hybrid monetary system, in which central banks issue public money as a low-risk instrument, while more risky lending is left to private institutions. Such a hybrid monetary system, if it functions well, combines the advantages of various public and private arrangements (Hockett and Omarova 2017). Full reserve banking and sovereign money proposals reject hybridity in favor of a purely public monetary system (A. Jackson and Dyson 2012; Weber 2018), while free bankers favor an entirely privatized system (Hayek 1976). Among those who support a hybrid system, there remains a broad range of options from financial systems subject to strict credit controls 
(Bezemer et al. 2021; Monnet 2018) to the laissez-faire approaches associated with precrisis Basel II regulation (Tarullo 2008). Our conception of monetary sovereignty is compatible with these different approaches to monetary governance.

Although there is no a priori connection between our conception and any particular segment, monetary sovereignty manifests itself in very distinct ways in the individual segments of the credit money system. To flesh out what it means for states to make their own economic policy within the constraints set by the global credit money system, we will now analyze the different ways in which states can govern money. They are able to control the issuance of public money through central bank design (4.1), regulate private-public money through banking regulation and monetary policy (4.2), and manage private money through laissez-faire, bans, accommodation, or attempts to outcompete it (4.3).

\subsection{Controlling issuance of public money}

A state's key discretionary choices for issuing public money concern the status and the design of its central bank-its institutional organization, mandate and permissible operations (van 't Klooster 2022). The design of the central bank determines who decides what regarding public money creation, and hence determines the size and accessibility of the pure public money segment within a monetary jurisdiction. The setup of the public segment is also a powerful lever to shape the private-public and private segments, as we will see in more detail below.

From the standpoint of effective monetary sovereignty, there is no obviously correct way to design the political structures for public money creation. Despite considerable harmonization since the 1980s, the institutional organization, mandates, and actual operations of central banks continue to differ quite substantially (Johnson 2016; Lastra 
2015). First, concerning formal organization, a state makes choices with regard to its role as state bank and bankers' bank (Conti-Brown 2016), its level of democratic accountability and independence from government interference (van 't Klooster 2020; Tucker 2018), as well as the scope of international monetary cooperation (H. James 2012). Second, concerning the mandate, central banks have historically been closely connected to government expenditures, in particular war finance, converting notes, and managing international trade for foreign exchange conversion. In the era of embedded liberalism, central banks were given numerous economic policy tasks but since 1980 their primary responsibility has increasingly narrowed to maintaining price stability (Garriga 2016). Third, concerning actual instruments, the way in which central banks create money has evolved considerably over time (Bindseil 2004; van 't Klooster and Fontan 2020) as has the degree of coordination with fiscal authorities (Monnet 2021).

In light of the constraints that states face individually, effective monetary sovereignty can be increased by sharing governance structures for controlling public money (Cohen 1998, chap. 4). From a perspective of Westphalian monetary sovereignty, membership in a monetary union is often seen as involving a dramatic loss of control over public money issuance (Proctor 2012). However, it is a contested question how membership in a monetary union impacts the state's ability to achieve its economic policy objectives (Gadha et al. 2021; Pigeaud and Sylla 2021; Viehoff 2018). A more modest loss of unilateral control over money occurs when central banks provide swap lines to each other. The Federal Reserve and the ECB have allowed other states to issue public money offshore, which allows them to backstop offshore money within their monetary jurisdiction. This has been seen to erode Westphalian monetary sovereignty because it challenges the central bank's role as monopoly issuer of the 
currency (Destais 2016). Yet, from a perspective of effective sovereignty, swap lines have contributed to achieving economic policy objectives in stabilizing the global credit money system during the crisis. The conception of monetary sovereignty that we propose is compatible with such different views on the objectives of economic policy and how to achieve them.

\subsection{Regulating private-public money}

The Westphalian conception of monetary sovereignty focuses on what states can do without interference from other states. States are thought of as sovereign as long as they can regulate financial institutions domiciled within their territory. In this regard, the Westphalian conception has a narrow territorial focus that abstracts from what economic policy objectives states can achieve by regulating private money.

For private-public money, effective monetary sovereignty consists in the ability of states to design the public-private segment in their monetary jurisdiction. In principle, this applies to both onshore money denominated in that state's unit of account and offshore money denominated in other units of account. We distinguish two means for states to do this: first, regulating the regulated banking sector; and second, designing their monetary policy framework.

Banking regulation determines under what conditions banks and other financial institutions are allowed to issue new credit money. One crucial objective of banking regulation has traditionally been financial stability: preventing the default of individual banks as well as banking crises (Ricks 2016; Tarullo 2008). To this end, states seek to regulate the financial risks that banks are allowed to take. In the post-war era, states 
regulated bank deposit creation through detailed prescriptions (Bezemer et al. 2021; Monnet 2018). Since the 1980s, banking supervision has become more hands-off, leaving money creation to be guided primarily by the profit motive. The post-2008 macroprudential turn has led new concerns about cyclicality and environmental sustainability to once again inform banking governance (van 't Klooster 2021; Thiemann 2019). Effective monetary sovereignty depends on what states can actually achieve but is compatible with each of these objectives.

Since a state's monetary jurisdiction and the monetary area often do not overlap, the ability of states to regulate banks is constrained by competitive dynamics and the prominence of cross-border transactions (Palan, Murphy, and Chavagneux 2013; Zucman 2015). Offshore money constitutes a powerful challenge to the ability of states to achieve their economic policy objectives. The offshore space o has become a venue not only to escape financial regulation but also to avoid taxes and launder money. For states whose citizens and firms use such services, offshore finance undermines their monetary sovereignty (Binder 2019).

To deal with these challenges, states coordinate their regulatory activities in global fora such as the G20, the Basel Committee on Banking Supervision, and the Financial Stability Board (Brummer 2015). While the coordination of banking regulation may involve giving up national discretion, it can improve the ability of the state to achieve the objectives of regulation. The same is true for giving up control over the regulation of cross-border financial flows (Dietsch 2015). States that are not part of the exclusive fora of banking regulators are largely rule-takers (Jones 2020). States who rely on finance provided outside its monetary jurisdiction lack the ability to apply its rules to begin with. Being integrated in 
such international regulatory bodies and influencing their policies increases a state's effective monetary sovereignty.

The second way in which states exercise control over their banking system is through monetary policy. By changing the conditions under which banks have access to central bank credit, states have considerable sway over bank lending. The ways in which states have sought to steer the creation of private-public money within their monetary jurisdiction have varied considerably over time (Bindseil 2004; van 't Klooster and Fontan 2020). In the 1990s, central banks converged on the use of short-term interest rates as the most important monetary policy tool. Banks' reliance on central bank refinancing operations makes this tool particularly effective for the regulated banking system, even if its effects reverberate through the entire financial system. More recently, central banks have turned to a host of unconventional monetary policy tools, such as large-scale financial asset purchases (socalled Quantitative Easing), to influence non-bank segments of their financial system directly (Musthaq 2021). Central bank swap lines are a starting point for more international coordination of monetary policy, which may help states regain effective monetary sovereignty vis-à-vis offshore money creation.

Effective monetary sovereignty in this field means having the ability to flexibly adapt the monetary policy strategy to a changing macro-financial environment. States that cannot use their monetary policy for these purposes, or whose banking system relies on a unit of account for which they do not control monetary policy to begin with, are limited in their monetary sovereignty. 


\subsection{Managing private money}

Private moneys are monetary instruments whose issuers lack access to public backstops and usually fall outside the strict regulatory framework applied to banks. Although such issuers are subject to only modest regulation and less responsive to monetary policy, states retain the ability to manage private money forms. Being able do so is today a crucial part of monetary sovereignty.

The normative assessment of the private money segment differs profoundly. From the perspective of critics, the emergence of new private money forms is an important driver of financial instability (Pistor 2017; Ricks 2016). During an extended economic upturn, the financial system will tend to issue new money forms which fund increasingly speculative investments (Kindleberger and Aliber 2005; Minsky 2008). In a panic, financial markets lose confidence in these instruments, which often forces governments to integrate them into the private-public segment (Murau 2017b). This means that the most aggressive private issuers acquire new on-balance-sheet credit money balances which public authorities are forced to guarantee. In this way, unregulated private money can undermine monetary sovereignty by forcing onto states unwanted monetary instruments.

A more optimistic perspective sees the private money segment as a legitimate source of funding for risky, potentially path-breaking investments and financial innovation. Historical experience shows that the prevalence of shadow money instruments in one form or another is a recurring byproduct of capitalist development (Schumpeter 1912). It is here where the largest fluctuations over the financial cycle take place, and where transformational changes of the financial and the real economy often materialize. As private 
money is often backed by sovereign debt it also facilitates states in funding their expenditures.

It is hard to determine ex ante which instruments are likely to develop into private money and what their connection to economic policy objectives will be. This poses a specific challenge to states for dealing with them. In the run up to the 2007-9 financial crisis, various instruments of the shadow banking system—often termed 'shadow money' (Pozsar 2014)— became part of the private money supply. While the regulatory community initially perceived them as beneficial, they turned out to be an important driver of the crisis. The past years have seen a rampant proliferation of assets based on the blockchain technology. So far, as we saw, these instruments have as a rule failed to stabilize their value sufficiently to serve as money for a state-issued unit of account.

Accordingly, states face difficult choices in how to maintain their monetary sovereignty in the face of new private moneys (Hayes 2021; Murau 2017a; Viñuela, Sapena, and Wandosell 2020). One policy is to pursue a ban of private money forms, forcing nonbank financial institutions to give up par clearance or prohibit their operations entirely (Bindseil, Papsdorf, and Schaaf 2022). Similarly, recent proposals for CDBCs are sometimes presented as a means to outcompete private cryptocurrencies (Brooks 2021). In contrast, a policy of accommodation provides private instruments with liquidity backstops on the central bank's balance sheet or measures for solvency insurance. Instead of fighting back, states can also accept and even foster a purely private segment within their domestic monetary jurisdiction. Acknowledging is not the same as ignoring and involves monitoring risks and vulnerabilities emerging out of an expanding private money supply. Monetary sovereignty then manifests itself in a laissez-faire approach that leaves shadow money 
creation to itself. What is crucial from a perspective of effective sovereignty is that these choices are made in accordance with the state's political procedures in ways that support its objectives. 


\section{Conclusion}

We have proposed a conception of monetary sovereignty that fits the reality of today's global credit money system. We propose to think of monetary sovereignty as the ability of states to use tools for monetary governance to achieve their economic policy objectives. Monetary governance involves the control of pure public money, regulation of private-public money and management of private money within the state's monetary jurisdiction.

By rethinking monetary sovereignty, we address the four objections to the Westphalian conception that we outlined in section 3. First, where the Westphalian conception is focused on central banks issuing public money, effective monetary sovereignty emphasizes monetary governance across all three segments of the monetary system. Second, instead of the Westphalian vision of a monetary system of equal sovereign states, the effective conception focuses on what states can do. It thereby highlights the privilege of a few states and the woes of others. Through a detailed study of effective monetary sovereignty, we get a better understanding of how states are doing and what they might owe to each other. Third, as it does not privilege public money, the effective conception is able to acknowledge the complex trade-offs involved in membership in a monetary union. Finally, unlike the Westphalian conception, our approach does not prescribe any particular economic policy goals. For these reasons, the effective conception makes monetary sovereignty an adequate concept for reflecting on the state's position in today's global credit money system.

A reconsideration of monetary sovereignty should pave the way for more quantitative and qualitative enquiry into what states can effectively do in the face of financial globalization. This applies at least to three different avenues of future research. 
First, we need a much better understanding of the real constraints that states face in governing money. The Westphalian world is one where sovereignty can be read off the legal competences of the state and the way these are constrained by international treaties. However, if monetary sovereignty is understood in terms of national currencies, then all states that issue and regulate one are equally sovereign. Conversely, if monetary sovereignty means having control over money creation within a territory, no state-not even the UShas any monetary sovereignty to speak of. Our conception broadens the focus of how money shapes what states can do but understanding the constraints of states requires detailed economics and institutional analysis. Moving the focus to effective sovereignty helps make sense of crucial differences between Bangladesh, Denmark and the US, which are all monetary sovereigns in a Westphalian sense. It also raises new comparative questions about a country like the Netherlands that gave up its national currency but gained a prominent role in governing a global currency.

Second, rather than focusing on a status that states may or may not have, effective monetary sovereignty requires us to think about monetary governance and how it allows states to achieve their objectives. An adequate comparison of individual states requires considering all three segments of the domestic monetary system-how do cryptocurrencies and other shadow money forms constrain states? Due to the reality of offshore money creation, no state faces an easy choice between giving up fixed exchange rates or retaining an independent monetary policy. An individual state's arrangement often cannot be chosen unilaterally: Global banking competition constrains the ability of states to effectively regulate their banking system, for which the Basel Committee and other transnational regulatory bodies provide only an imperfect fix. States in the periphery of the global credit 
money system often deal with a domestic economy where citizens save, borrow and transact using a foreign unit of account. Going forward states face the epochal challenge of decarbonizing their economy, while adapting their society to an increasingly derailed climate. Some states are better off than others but each state faces its own challenges. No state, not even the US, has complete monetary sovereignty. To study monetary sovereignty empirically, research should not just consider legal constraints that result from other states and international treaties, but also those resulting from domestic institutions and market forces.

Finally, the study of effective monetary sovereignty raises new normative questions. Since states face trade-offs, determining what constitutes an increase in monetary sovereignty is in part a function of weighing policy priorities. The study of monetary sovereignty thus unavoidably confronts researchers with the question of what policies states should and should be able to pursue. Judgment comes in when drawing on that evidence to say that one state is better placed in the global credit money system than another. In this regard, the study of monetary sovereignty provides a more fine-grained account of how states are doing than a simple hierarchy of currencies. An obvious next step would be the design of a monetary sovereignty index. 


\section{References}

Alami, Ilias et al. 2021. International Financial Subordination: A Critical Research Agenda. London: University of Greenwich Business School. Working Paper. https://gala.gre.ac.uk/id/eprint/33233/ (January 19, 2022).

Aldasoro, Iñaki, and Torsten Ehlers. 2018. The Geography of Dollar Funding of Non-US Banks. Bank for International Settlements. BIS Quarterly Review.

Avdjiev, Stefan, Robert McCauley, and Hyun Song Shin. 2015. Breaking Free of the Triple Coincidence in International Finance. Bank for International Settlements. BIS Working Papers.

Awrey, Dan. 2017. "Brother, Can You Spare a Dollar? Designing an Effective Framework for Foreign Currency Liquidity Assistance." Columbia Business Law Review.

Bangladesh Bank. 2019. "Treasury Bills \& BGTB Auction.” https://www.bb.org.bd/monetaryactivity/treasury.php (May 24, 2019).

- - . 2021. "Monetary Policy Statement 2021-2022."

Berlin, Isaiah. 1969. Four Essays on Liberty. Oxford University Press.

Bezemer, Dirk, Josh Ryan-Collins, Frank van Lerven, and Lu Zhang. 2021. "Credit Policy and the 'Debt Shift' in Advanced Economies." Socio-Economic Review (mwab041). https://doi.org/10.1093/ser/mwab041 (November 25, 2021).

Binder, Andrea. 2019. "All Exclusive. The Politics of Offshore Finance in Mexico." Review of International Political Economy https://doi.org/10.1080/09692290.2019.1567571.

Bindseil, Ulrich. 2004. Monetary Policy Implementation: Theory--Past--Present. Oxford; New York: Oxford University Press.

Bindseil, Ulrich, Patrick Papsdorf, and Jürgen Schaaf. 2022. The Encrypted Threat: Bitcoin's Social Cost and Regulatory Responses, SUERF Policy Notes ... SUERF - The European Money and Finance Forum. . SUERF Policy Note. https://www.suerf.org/policynotes/38771/the-encrypted-threat-bitcoins-socialcost-and-regulatory-responses (January 16, 2022).

Blyth, Mark. 2002. Great Transformations: Economic Ideas and Institutional Change in the Twentieth Century. Cambridge University Press.

Bonizzi, Bruno, Annina Kaltenbrunner, and Jo Michell. 2019. "Monetary Sovereignty Is a Spectrum: Modern Monetary Theory and Developing Countries." real-world economics review 89: 46-61. 
Braun, Benjamin. 2022. "Fueling Financialization. The Economic Consequences of Funded Pensions." New Labor Forum 31(1): 70-79.

Braun, Benjamin, Arie Krampf, and Steffen Murau. 2021. "Financial Globalization as Positive Integration: Monetary Technocrats and the Eurodollar Market in the 1970s." Review of International Political Economy 28(4): 794-819.

Brooks, Skylar. 2021. Discussion Papers Revisiting the Monetary Sovereignty Rationale for CBDCs. Bank of Canada. https://ideas.repec.org/p/bca/bocadp/21-17.html (January 19, 2022).

Bruin, Boudewijn de, Lisa Herzog, Martin O'Neill, and Joakim Sandberg. 2018. "Philosophy of Money and Finance." In The Stanford Encyclopedia of Philosophy, ed. Edward N. Zalta. Stanford University.

Brummer, Chris. 2015. Soft Law and the Global Financial System. Cambridge: Cambridge University Press.

Burn, Gary. 1999. "The State, the City and the Euromarket." Review of International Political Economy 6(2): 225-61.

——- 2006. The Re-Emergence of Global Finance. London: Palgrave Macmillan.

Cohen, Benjamin J. 1998. The Geography of Money. Ithaca and London: Cornell University Press.

-_- 2015. Currency Power: Understanding Monetary Rivalry. Princeton University Press.

COM. 1990. One Market, One Money. An Evaluation of the Potential Benefits and Costs of Forming an Economic and Monetary Union. Brussels: European Commission (COM). Report of the Directorate-General for Economic and Financial Affairs.

Conti-Brown, Peter. 2016. The Power and Independence of the Federal Reserve. Princeton: Princeton University Press.

Cordelli, Chiara, and Jonathan Levy. 2021. "The Ethics of Global Capital Mobility." American Political Science Review: 1-14.

De Grauwe, Paul. 2012. Economics of Monetary Union. 9th ed. Oxford: Oxford University Press.

Denbee, Ed, Carsten Jung, and Francesco Paternò. 2016. Stitching Together the Global Financial Safety Net. Bank of England. Financial Stability Paper.

Destais, Christophe. 2016. "Central Bank Currency Swaps and the International Monetary System." Emerging Markets Finance and Trade 52(10): 2253-66. 
Dietsch, Peter. 2011. "Rethinking Sovereignty in International Fiscal Policy." Review of International Studies 37(5): 2107-20.

- - 2015. Catching Capital: The Ethics of Tax Competition. Oxford University Press.

——_. 2021. "Designing the Fiscal-Monetary Nexus: Policy Options for the EU." Review of Social Economy 0(0): 1-18.

Dutta, Sahil Jai, Ruben Kremers, Fabian Pape, and Johannes Petry. 2020. "Critical MacroFinance: An Introduction." Finance and Society 6(1): 34-44.

Eichengreen, Barry, and Masahiro Kawai. 2015. "Introduction and Overview." In Renminbi Internationalization. Achievement, Prospects, and Challenges, Washington, D.C.: Brooking Institution Press.

Eichengreen, Barry, Arnaud Mehl, and Livia Chiţu. 2017. How Global Currencies Work. Past, Present and Future. Princeton and Oxford: Princeton University Press.

Fama, Marco, Andrea Fumagalli, and Stefano Lucarelli. 2019. "Cryptocurrencies, Monetary Policy, and New Forms of Monetary Sovereignty." International Journal of Political Economy 48(2): 174-94.

Fleming, J. Marcus. 1962. "Domestic Financial Policies under Fixed and Floating Exchange Rates." IMF Staff Paper 9(3): 369-80.

Frieden, Jeffry A. 2015. Currency Politics. The Political Economy of Exchange Rate Policy. Princeton: Princeton University Press.

Fritz, Barbara, Luiz F. de Paula, and Daniela Magalhães Prates. 2018. "Global Currency Hierarchy and National Policy Space. A Framework for Peripheral Countries." European Journal of Economics and Economic Policies: Intervention 15(2): 208-18.

Gabor, Daniela. 2016. “The (Impossible) Repo Trinity. The Political Economy of Repo Markets." Review of International Political Economy 23(6): 967-1000.

- - 2020. "Critical Macro-Finance. A Theoretical Lens." Finance and Society 6(1): 4555.

Gabor, Daniela, and Cornel Ban. 2016. "Banking on Bonds. The New Links Between States and Markets." Journal of Common Market Studies 54(3): 617-35.

Gabor, Daniela, and Jakob Vestergaard. 2016. Towards a Theory of Shadow Money. Institute for New Economic Thinking. INET Working Paper.

Gadha, Maha Ben et al., eds. 2021. Economic and Monetary Sovereignty in 21st Century Africa. London: Pluto Press. 
Garriga, Ana Carolina. 2016. "Central Bank Independence in the World: A New Data Set." International Interactions 42(5): 849-68.

Guter-Sandu, Andrei, and Steffen Murau. 2021. "The Transformation of Eurozone Fiscal Governance. Mitigating Fiscal Discipline through a Proliferation of Off-Balance-Sheet Fiscal Agencies." New Political Economy https://doi.org/10.1080/13563467.2021.1910648.

Harris, Max. 2021. Monetary War and Peace. London, Washington, Paris, and the Tripartite Agreement of 1936. Cambridge and New York: Cambridge University Press.

Hayek, Friedrich August von. 1976. Denationalisation of Money - The Argument Refined. An Analysis of the Theory and Practice of Concurrent Currencies. London: The Institute of Economic Affairs.

Hayes, Adam. 2021. "World Monies or Money-Worlds. A New Perspective on Cryptocurrencies and Their Moneyness." Finance and Society EarlyView: 1-10.

He, Dong, and Robert McCauley. 2012. Eurodollar Banking and Currency Internationalisation. Bank for International Settlements. BIS Quarterly Review.

Helleiner, Eric. 1994. States and the Reemergence of Global Finance. From Bretton Woods to the 1990s. Ithaca and London: Cornell University Press.

- - - 2003. The Making of National Money. Territorial Currencies in Historical Perspective. Ithaca and London: Cornell University Press.

Herzog, Lisa. 2019. "Global Reserve Currencies from the Perspective of Structural Global Justice: Distribution and Domination." Critical Review of International Social and Political Philosophy 0(0): 1-23.

- - 2021. "Global Reserve Currencies from the Perspective of Structural Global Justice: Distribution and Domination." Critical Review of International Social and Political Philosophy 24(7): 931-53.

Hockett, Robert, and Saule Omarova. 2017. "The Finance Franchise." Cornell Law Review 102(5): 1143.

Iqbal, Shaheen. 2019. "Offshore Banking in Bangladesh and Impact of Recent Regulatory Changes." The Financial Express. https://thefinancialexpress.com.bd/views/offshore-banking-in-bangladesh-andimpact-of-recent-regulatory-changes-1573050507 (January 20, 2022).

Ito, Hiro, and Robert McCauley. 2018. A Key Currency View of Global Imbalances. Bank for International Settlements. BIS Working Papers. 
Jackson, Andrew, and Ben Dyson. 2012. Modernising Money: Why Our Monetary System Is Broken and How It Can Be Fixed. London: Positive Money.

Jackson, Robert H. 1992. Quasi-States: Sovereignty, International Relations and the Third World. Cambridge: Cambridge University Press.

James, Aaron. 2012. Fairness in Practice: A Social Contract for a Global Economy. New York: Oxford University Press.

James, Harold. 2012. Making the European Monetary Union. Harvard University Press.

Johnson, Juliet. 2016. Priests of Prosperity. Ithaca: Cornell University Press.

Jones, Emily. 2020. The Political Economy of Bank Regulation in Developing Countries. Oxford: Oxford University Press.

Kelton, Stephanie. 2020. The Deficit Myth: Modern Monetary Theory and the Birth of the People's Economy. New York: Hachette.

Kindleberger, Charles Poor, and Robert Z. Aliber. 2005. Manias, Panics, and Crashes: A History of Financial Crises. 5. ed. Basingstoke: Palgrave Macmillan.

King, Mervyn. 2016. The End of Alchemy: Banking, the Global Economy and the Future of Money. Little, Brown Book Group Limited.

van 't Klooster, Jens. 2020. "The Ethics of Delegating Monetary Policy." Journal of Politics 82(2): 587-99.

van 't Klooster, Jens. 2021. "Technocratic Keynesianism: A Paradigm Shift without Legislative Change." New Political Economy. https://doi.org/10.1080/13563467.2021.2013791 (January 16, 2022).

van 't Klooster, Jens. 2022. "Central Banks." In The Cambridge Handbook of Constitutional Theory, eds. Richard Bellamy and Jeff King. Cambridge: Cambridge University Press. https://osf.io/4t2fr.

van 't Klooster, Jens, and Clément Fontan. 2020. "The Myth of Market Neutrality: A Comparative Study of the European Central Bank's and the Swiss National Bank's Corporate Security Purchases." New Political Economy 25(6): 865-79.

Lastra, Rosa. 2015. International Financial and Monetary Law. 2nd ed. Oxford: Oxford University Press. https://econpapers.repec.org/bookchap/oxpobooks/9780199269341.htm (May 26, 2019).

Libra Association Members. 2018. "An Introduction to Libra. White Paper.” 
Loick, Daniel. 2019. A Critique of Sovereignty. London: Rowman \& Littlefield International, Ltd.

Mabbett, Deborah, and Waltraud Schelkle. 2015. "What Difference Does Euro Membership Make to Stabilization? The Political Economy of International Monetary Systems Revised." Review of International Political Economy 22(3): 508-34.

McCauley, Robert. 2020. "The Global Domain of the Dollar. Eight Questions." Atlantic Economic Journal 48(4): 421-29.

Mehrling, Perry. 2011. The New Lombard Street. How the Fed Became the Dealer of Last Resort. Princeton and Oxford: Princeton University Press.

- - 2015. "Elasticity and Discipline in the Global Swap Network." International Journal of Political Economy 44(4): 311-24.

——. 2016. "Beyond Bancor." Challenge 59(1): 22-34.

Meyer, Marco. 2021. “Dealing Fairly with Trade Imbalances in Monetary Unions.” Politics, Philosophy \& Economics 20(1): 45-66.

Minsky, Hyman P. 2008. Stabilizing an Unstable Economy. New ed. New York, [NY]: McGraw-Hill.

Mitchell, William, L. Randall Wray, and Martin Watts. 2019. Macroeconomics. Macmillan Education UK.

Mitchell-Innes, Alfred. 1914. "The Credit Theory of Money." The Banking Law Journal 31: 151-68.

Mody, Ashoka. 2018. Eurotragedy: A Drama in Nine Acts. Oxford: Oxford University Press.

Monnet, Eric. 2018. Controlling Credit: Central Banking and the Planned Economy in Postwar France, 1948-1973. Cambridge University Press.

_-_. 2021. La Banque Providence: Démocratiser Les Banques Centrales et La Monnaie. Paris: Seuil.

Mundell, Robert A. 1963. "Capital Mobility and Stabilization Policy under Fixed and Flexible Exchange Rates." Canadian Journal of Economic and Political Science 29(4): 475-85.

Murau, Steffen. 2017a. "Shadow Money and the Public Money Supply. The Impact of the 2007-2009 Financial Crisis on the Monetary System." Review of International Political Economy 24(5): 802-38.

- - . 2017b. "The Political Economy of Private Credit Money Accommodation. A Study of Bank Notes, Bank Deposits and Shadow Money." PhD thesis. City, University of London. 
- - . 2018. "Offshore Dollar Creation and the Emergence of the Post-2008 International Monetary System."

Murau, Steffen, Fabian Pape, and Tobias Pforr. 2021. The Hierarchy of the Offshore US-Dollar System. On Swap Lines, the FIMA Repo Facility and Special Drawing Rights. Boston, MA: Global Development Policy Center, Global Economic Governance Initiative (GEGI), Boston University. GEGI Study February 2021.

Murau, Steffen, and Tobias Pforr. 2020. "What Is Money in a Critical Macro-Finance Framework?" Finance and Society 6(1): 56-66.

Murau, Steffen, Joe Rini, and Armin Haas. 2020. "The Evolution of the Offshore US-Dollar System. Past, Present and Four Possible Futures." Journal of Institutional Economics 16(6): 767-83.

Musthaq, Fathimath. 2021. "Unconventional Central Banking and the Politics of Liquidity." Review of International Political Economy 0(0): 1-26.

Naqvi, Natalya. 2019. "Manias, Panics and Crashes in Emerging Markets: An Empirical Investigation of the Post-2008 Crisis Period." New Political Economy 24(6): 759-79.

Palan, Ronen, Richard Murphy, and Christian Chavagneux. 2013. Tax Havens: How Globalization Really Works. Cornell University Press.

Paterson, Matthew. 2021. "Climate Change and International Political Economy: Between Collapse and Transformation." Review of International Political Economy 28(2): 394405.

Philpott, Daniel. 2011. "Sovereignty." In The Oxford Handbook of the History of Political Philosophy, ed. George Klosko. Oxford University Press. http://oxfordhandbooks.com/view/10.1093/oxfordhb/9780199238804.001.0001/ oxfordhb-9780199238804-e-32 (March 13, 2019).

Pigeaud, Fanny, and Ndongo Samba Sylla. 2021. Africa's Last Colonial Currency: The CFA Franc Story. London: Pluto Press.

Pistor, Katharina. 2017. "From Territorial to Monetary Sovereignty." Theoretical Inquiries in Law 18(2).

Pozsar, Zoltan. 2014. Shadow Banking. The Money View. Office of Financial Research. Working Paper.

Proctor, Charles. 2012. Mann on the Legal Aspect of Money. 7th ed. Oxford: Oxford University Press.

Rawls, John. 1999. A Theory of Justice. Revised Edition. Cambridge, MA: Belknap Press. 
Reddy, Sanjay G. 2003. “Developing Just Monetary Arrangements." Ethics \& International Affairs 17(1): 81-93.

Ricks, Morgan. 2016. The Money Problem. Rethinking Financial Regulation. Chicago and London: The University of Chicago Press.

Ronzoni, Miriam. 2009. "The Global Order: A Case of Background Injustice? A PracticeDependent Account." Philosophy \& Public Affairs 37(3): 229-56.

- - - 2012. "Two Conceptions of State Sovereignty and Their Implications for Global Institutional Design." Critical Review of International Social and Political Philosophy 15(5): 573-91.

Roos, Jerome. 2019. Why Not Default? The Political Economy of Sovereign Debt. Princeton: Princeton University Press.

Schumpeter, Joseph Alois. 1912. The Theory of Economic Development. An Inquiry into Profits, Capital, Credit, Interest, and the Business Cycle. Cambridge, MA: Harvard University Press.

Smoleńska, Agnieszka, and Jens van 't Klooster. 2022. "A Risky Bet: Climate Change and the EU's Microprudential Framework for Banks." Journal of Financial Regulation. https://doi.org/10.1093/jfr/fjac002 (April 6, 2022).

Strange, Susan. 1971. Sterling and British Policy. A Political Study of an International Currency in Decline. London and New York: Oxford University Press.

- - 1996. The Retreat of the State: The Diffusion of Power in the World Economy. Cambridge University Press.

Tarullo, Daniel K. 2008. Banking on Basel: The Future of International Financial Regulation. Peterson Institute.

Thiemann, Matthias. 2019. "Is Resilience Enough? The Macroprudential Reform Agenda and the Lack of Smoothing of the Cycle." Public Administration 97(3): 561-75.

Tooze, Adam. 2018. Crashed. How a Decade of Financial Crises Changed the World. New York: Viking.

Tucker, Paul. 2018. Unelected Power: The Quest for Legitimacy in Central Banking and the Regulatory State. Cambridge (MA): Harvard University Press.

Verdun, Amy. 2021. "The Greatest of the Small? The Netherlands, the New Hanseatic League and the Frugal Four." German Politics 0(0): 1-21.

Viehoff, Juri. 2018. “Eurozone Justice." Journal of Political Philosophy 26(3): 388-414. 
Viñuela, Carlos, Juan Sapena, and Gonzalo Wandosell. 2020. "The Future of Money and the Central Bank Digital Currency Dilemma." Sustainability 12(22): 9697.

Weber, Beat. 2018. Democratizing Money? Cambridge: Cambridge University Press. https://ideas.repec.org/b/cup/cbooks/9781107195813.html (September 9, 2020).

Wiedenbrüg, Anahí. 2021. "Responsibility For Financial Crises." American Journal of Political Science 65(2): 460-72.

Wollner, Gabriel. 2018. "Morally Bankrupt: International Financial Governance and the Ethics of Sovereign Default." Journal of Political Philosophy 26(3): 344-67.

Wood, James D. G. 2018. "Mortgage Credit: Denmark's Financial Capacity Building Regime." New Political Economy.

Wullweber, Joscha. 2020. “The Politics of Shadow Money. Security Structures, Money Creation and Unconventional Central Banking." New Political Economy https://doi.org/10.1080/13563467.2019.1708878.

Zimmermann, Claus D. 2013. A Contemporary Concept of Monetary Sovereignty. Oxford: Oxford University Press.

Zucman, Gabriel. 2015. The Hidden Wealth of Nations: The Scourge of Tax Havens. University of Chicago Press. 